\section{Goals of Consumers in the Context of Slow Tourism}

\author{
Slavica Tomić, Ksenija Leković, Dražen Marić
}

Jel klasifikacija: Z32, M31

\section{INTRODUCTION}

Recently, the field of tourism has witnessed changes which result in the emergence of new forms of tourism. People travel and experience different forms of tourism such as ecotourism, cultural tourism, heritage tourism, green tourism, health tourism, etc. Two driving forces - environmental sustainability and personal/social well-being constitute the basis of these forms (Moore, 2012). Slow tourism, as a special form of tourism, is also emerging from these environmental and personal concerns.

The concept of slow tourism is relatively new and follows two essential principles: taking time and attachment to a particular place (Yurtseven and Kaya, 2011). This form of tourism subsumes different lifestyles that are connected to Slow Food, Slow Cities and Slow Transportation (Fullagar et al., 2012). According to Conway and Timms (2012) slow tourism connects "travelling for pleasure" with the benefits they bring to local stakeholders.

In order to fulfill consumers" desire to "slow down" Caffyn (2012) outlines a few basic elements of slow tourism: minimizing travel distance; maximizing the time available for the trip; relaxing, refreshing the mind/ body; contact with local people, culture and heritage; eating at local restaurants; shopping in local markets or directly from producers; learning a new skills; minimizing mechanization and technology; experiencing authenticity; minimizing carbon footprint.

In times when consumers seek a more relaxed rhythm, authentic experiences, cultural and natural resources in destinations that they visit, Vojvodina, as a tourist destination, is very suitable for the development of slow tourism. In this paper, the authors examine whether there are differences in consumer goals dependent upon their demographic characteristics.

\section{LITERATURE REVIEW}

\subsection{Special form of tourism - Slow tourism}

The concept of slow tourism is relatively new (Oh et al., 2016) and the guiding line of "slow" is an antithesis to "fast" with its connection to ecology and sustainable development. In other words, it stands as the

\begin{abstract}
The concept of slow tourism is gaining attention in terms of emphasized need for slowing down the pace of life. This concept is tied to sustainable tourism and linked to social movements such as: "Slow Food" (authentic, local food), "Slow Cities" (environmentally responsible and peaceful environment) and "Slow Transportation" (local buses and trains). This study provides insights into the phenomenon of slow tourism from the perspective of a goal-directed consumption process. The research was based on a model consisting of six slow tourism motivations (relaxation, self-reflection, escape, novelty-seeking, engagement, and discovery), two goals of slow tourism (revitalization and self-enrichment), and travel outcomes (satisfaction, future return intention, and recommendations). The sample included 320 respondents from the territory of the Republic of Serbia who had visited some of the destinations in Vojvodina labeled as "slow place" in the past two years.
\end{abstract}

Keywords: Slow Tourism, consumer behavior, goals of consumers, Vojvodina 
antithesis to mass-tourism as potentially sustainable socially, economically and environmentally (Conway and Timms, 2010). The idea of "slow" reflects the social phenomenon generated by characteristics of the modern society such as fast, over-scheduled, task-orientated, and stressful life. Authors Dickinson and Lumsdon (2010) define slow tourism as a conceptual framework that involves people who travel to destinations more slowly overland and stay longer in a chosen destination. Doing so, consumers make real and meaningful connections with people, places, culture, food, heritage and environment (Caffyn, 2012). According to Yurtseven and Kaya (2011) slow tourism highlights the engagement with a place, encouraging, at the same time, consumers to establish local routines and enjoy local food. In this way, slow tourism is about becoming a part of local life of the destination that consumers visit (Georgica, 2015).

According to several sources, major elements of slow tourism are: slow food, slow places and slow transportation (Dickinson and Lumsdon, 2010; Parasecoli and Lima, 2012; Long, 2013; Meng and Choi, 2016). The concept of slow tourism is rooted in the Slow Food Movement which is dedicated to a food concept that is based on the principles of high quality, eco-friendly standards, taste and authenticity. The concept evolved into the Slow City Movement - Cittaslow which means slow city (Yurtseven and Kaya, 2011). Cittaslow is an international network of small towns whose aim is to improve the quality of life, well-being and health. Some modes of transportation (local trains, local buses, cycling, walking) enhance slow experiences and often represent low-carbon means of travel (Meng and Choi, 2016; Fallon, 2012).

The product of slow tourism is characterized by a few main elements: (1) time; (2) conscious decision-making; (3) engaging the senses; (4) holiday duration and location (Guiver and McGrath, 2016). As previously mentioned, "slow" indicates a relationship with time and opposes "fast". According to Gardner (2009) "slow tourism is about making conscious choices" because consumers consider the impact of their travel on the local community. One of the main aspects of slow tourism is enjoying local food and drinks, which benefits the destination and offers the opportunity to connect with local people (Caffyn, 2012). In order to experience a destination more deeply tourists have to stay longer in places with a slower pace, which offer opportunities to walk, cycle and enjoy the countryside (Lumsdon and McGrath, 2011).

According to Georgica (2015) slow travelers stay in vacation rentals and experience the local cuisine of the destination. For them it is "something totally different from trips where travelers just follow the list of all must-sees and after getting home they realize that actually they need a holiday to recover".

\subsection{Goal-directed consumer behavior in Slow Tourism}

According to Bagozzi and Dholakia, much of consumer behavior is found to be goal-directed behavior (1999). Goals are defined as basic determinants of how a consumer looks at a given situation. In other words, goals "frame" the way consumers process information and act upon it (Lindenberg and Steg, 2007). In a situation where a goal becomes active, tension arises. In order to reduce discrepancy between the current state and the desired state, cognitive resources (attention, information processing, knowledge, attitudes, and motivation) are directed towards fulfillment of the active goals (Barbopoulos and Johansson, 2016).

Goals are not limited to end states. They include a variety of experiences, ongoing processes and happenings that are interconnected (Novak et al., 2003). Authors Bagozzi and Dholakia (1999) present an organizing model of the goal-directed consumer behavior process composed of six activities: (1) goal setting ("What are the goals I can pursue and why do I want to pursue them?"); (2) formation of a goal intention ("What is it for which I strive?"); (3) action planning ("How can I achieve my goal?"); (4) action initiation and control ("Am I making progress toward my goal?, "Is the goal still important to me?"); (5) goal attainment/failure ("To what degree have I achieved/failed to achieve my goal?"); (6) feedback reactions ("How do I feel about achieving/not achieving my goal?"). According to Oh et al. (2016) slow tourism can be defined as a goal-directed activity. In this context, revitalization of body and mind, while enjoying natural environment, could be a goal for a consumer. In order to fulfill this goal, the consumer has to choose the destination and the way to travel. The degree of goal fulfillment will determine consumers' satisfaction and behavior of consumers in future.

Goal-setting activities can be summarized in a goal hierarchy framework. According to Lindenberg and Steg (2007), three fundamental goals have been identified and described in the Goal Framing Theory: (1) gain goal - to guard or improve personal resources; (2) hedonic goal - to feel better right now; (3) normative goal - to act according to personal norms, the opinions of others and the society. In comparison with other goals, the hedonic goal is the most basic goal 
because it requires the least support from the social environment. The hedonic goal is related to sub-goals that improve the way one feels in a particular situation (seeking direct pleasure, seeking direct improvement in self-esteem, seeking excitement, etc.) (Barbopoulos and Johansson, 2017). In the context of slow tourism, the goal hierarchy includes: (1) subordinate goals (saving money for a trip), (2) focal goals (escape from everyday routine), and (3) superordinate goals (enriching the self through the trip). In this way, superordinate goals are the ultimate goals of slow tourism (Oh et al., 2016).

\section{METHODOLOGY}

The current research on slow tourism lacks empirical evidence that would fully explain this particular form of tourism (Oh et al., 2016). Therefore, the authors of this paper examine differences in goals of slow tourists, i.e. consumers of slow tourism based on their demographic characteristics (sex, age, education, monthly income).

In order to obtain data, a field research was conducted by using a paper-based and online questionnaires. The research was carried out from October to December 2017. The sample, defined prior to the research, consisted of approximately equal number of respondents from five cities that the study encompassed (Subotica $n=68$; Novi Sad $n=76$; Belgrade $\mathrm{n}=58$; Kragujevac $\mathrm{n}=54$; Niš $\mathrm{n}=64$ ). The research included all respondents who had travelled to at least one "slow place" destination in Vojvodina (Palić, a grange in Vojvodina, Fruška gora) in the past two years. The sample consisted of 198 women and 122 men. The majority of respondents were aged between 26 and 35, and 36 and 45, 69.3\% graduated from the faculty and had a monthly income of 600 euros.

The questionnaire was divided into three sections. The first section contained questions regarding general sociodemographic characheristics of respondents. The second section consisted of questions concerning the trip and the visit to a destination, while the third section was composed of statements depicting different attitudes to which participants had to respond within a five-point Likert scale (motivations and goals: 1 - I strongly disagree, 5 - I strongly agree; outcomes: 1 - very dissatisfied, 5 - very satisfied, 1 - terrible, 5 - delightful; 1 - very unlikely, 5 - very likely). The questionnaire was adjusted to a measurement scale employed by Oh et al. (2016) (Cronbach's Alpha coefficient for motivations $>0.944$; Cronbach's
Alpha coefficient for goals > 0.968; Cronbach's Alpha coefficient for outcomes $>0.832$ ).

In their research Oh et al. (2016) identified the following goals of a visit to a slow destination: 1) revitalization - refers to a state of both mental and physical vigor restored through a slow tourism, and 2) self-enrichment - a perceived degree of enhanced self-esteem, confidence, and self-assurance obtained as a result of slow tourism.

In this paper, the authors present a part of the research results that refer to goals of slow tourism consumers (revitalization - "I felt refreshed after visiting a destination", "I felt reinvigorated after visiting a destination", and self-enrichment - "I felt much better about myself as a result of this trip", "I felt fulfilled about myself as a result of this trip"). Based on the literature review and relevant research findings, the following hypotheses were formulated:

$\mathrm{H}_{1}$ : There is a statistically significant difference in goals of slow tourism between respondents based on their gender.

$\mathrm{H}_{2}$ : There is a statistically significant difference in goals of slow tourism between respondents based on their age.

$\mathrm{H}_{3}$ : There is a statistically significant difference in goals of slow tourism between respondents based on their montly income.

$\mathrm{H}_{4}$ : There is a statistically significant difference in goals of slow tourism between respondents based on their educational background.

The statistical software IBM SPSS version 20 was used for data processing and hypotheses testing.

\section{RESEARCH RESULTS}

\subsection{Determining a statistically significant difference in goals of slow tourism between respondents based on their gender}

For testing hypothesis $\mathrm{H}_{1}$ the independent samples t-test was applied. The test was used to examine the existence of a statistically significant difference in goals of slow tourism (goal 1 - self-enrichment, goal 2 - revitalization) between respondents based on their gender. The results are shown in Table 1 and Table 2.

With regard to goal 1 , the results revealed a statistically significant difference between female $(\mathrm{M}=4.15, \mathrm{SD}=1.227)$ and male respondents $(\mathrm{M}=3.81$, $\mathrm{SD}=1.382)$; $(320)=2.262, \mathrm{p}=0.025$. The difference 
TABLE 1. Group statistics

\begin{tabular}{|c|c|c|c|c|c|}
\hline & Sex & N & Mean & Std. Deviation & Std. Error Mean \\
\hline \multirow{2}{*}{ Goal 1 } & Female & 198 & 4.15 & 1.227 & .087 \\
& Male & 122 & 3.81 & 1.382 & .125 \\
\hline \multirow{2}{*}{ Goal 2 } & Female & 198 & 4.09 & 1.254 & .089 \\
\hline
\end{tabular}

SOURCE: Authors' calculation

TABLE 2. Independent samples test

\begin{tabular}{|c|c|c|c|c|c|c|c|c|c|}
\hline & \multicolumn{2}{|c|}{$\begin{array}{l}\text { Levene's Test } \\
\text { for Equallty of } \\
\text { Variances }\end{array}$} & \multicolumn{7}{|c|}{ tetest for Equality of Means } \\
\hline & \multirow[t]{2}{*}{$\mathbf{F}$} & \multirow[t]{2}{*}{ Sig. } & \multirow[t]{2}{*}{$\mathbf{t}$} & \multirow[t]{2}{*}{ df } & \multirow[t]{2}{*}{$\begin{array}{c}\text { Sig. } \\
\text { (2-tailed) }\end{array}$} & \multirow[t]{2}{*}{$\begin{array}{c}\text { Mean } \\
\text { Difference }\end{array}$} & \multirow[t]{2}{*}{$\begin{array}{l}\text { Std. Error } \\
\text { Difference }\end{array}$} & \multicolumn{2}{|c|}{$\begin{array}{l}95 \% \text { Confidence } \\
\text { Interval of the } \\
\text { Difference }\end{array}$} \\
\hline & & & & & & & & Lower & Lower \\
\hline Goal 1 & 5.442 & .020 & 2.262 & 233.275 & .025 & .345 & .152 & .044 & .645 \\
\hline Goal 2 & 1.378 & .241 & 1.992 & 318 & .047 & .292 & .146 & .003 & .581 \\
\hline
\end{tabular}

SouRCE: Authors' calculation

between mean values of characteristics per group (average difference $=0.35,95 \%$ CI: from 0.04 to 0.65 ) was small (eta-square $=0.02$ ). As far as goal 2 is concerned, the results indicated a significant difference between female $(\mathrm{M}=4.09, \mathrm{SD}=1.254)$ and male respondents $(\mathrm{M}=3.80, \mathrm{SD}=1.311) ; \mathrm{t}(320)=1.992, \mathrm{p}=0.047$. The difference between mean values of characteristics per group (average difference $=0.29,95 \%$ CI: from 0.003 to 0.58 ) was small (eta-square $=0.01$ ). Therefore, women and men differ considerably with regard to goals of slow tourism, which confirms hypothesis $\mathrm{H}_{1}$ - there is a statistically significant difference in goals of slow tourism between respondents based on their gender.

\subsection{Determining a statistically significant difference in goals of slow tourism between respondents based on their age}

In order to test hypothesis $\mathrm{H}_{2}$, one-way analysis of variance (one-way ANOVA) was employed. One-way analysis of variance was used to examine the existence of a statistically significant difference in goals of slow tourism (goal 1 - self-enrichment, goal 2 - revitalization) between respondents based on their age. The participants were divided into six age groups (group 1: 25 years old and younger; group 2: 26-35; group 3: 36-45; group 4: 46-55; group 5: 56-65; group 6: 66 and older). The research results are displayed in Table 3 and Table 4.

With regard to goal 1 , the results revealed a statistically significant difference $(\mathrm{p}<0.05)$ between all six groups $\mathrm{F}(5,314)=3.069, \mathrm{p}=0.010$. The actual difference between the groups' mean values was medium. The difference, expressed as eta-squared, was 0.05. Further comparison, using the Tukey HSD test, indicated that the mean value for group $1(M=3.66$; $\mathrm{SD}=1.533)$ differed significantly from the mean value for group $4(\mathrm{M}=4.48 ; \mathrm{SD}=0.916)$. Group $2(\mathrm{M}=4.05$; $\mathrm{SD}=1.267)$, group $3(\mathrm{M}=3.89 ; \mathrm{SD}=1.326)$, group 5 $(\mathrm{M}=4.46 ; \mathrm{SD}=0.784)$ and group $6(\mathrm{M}=5.00 ; \mathrm{SD}=0.000)$ did not show notable differences from groups 1 and 4. The significance regarding goal 2 was above the required threshold of 0.05 , which leads us to a conclusion that there is no statistically significant difference in goals between respondents based on their age structure. Having identified a significant difference only with regard to goal $1(\mathrm{p}<0.05)$, hypothesis $\mathrm{H}_{2}$ is partly confirmed.

\subsection{Determining a statistically significant difference in goals of slow tourism between respondents based on their income}

In order to test hypothesis $\mathrm{H}_{3}$, one-way analysis of variance (one-way ANOVA) was applied. One-way 


\section{marketing}

TABLE 3. Descriptive statistics

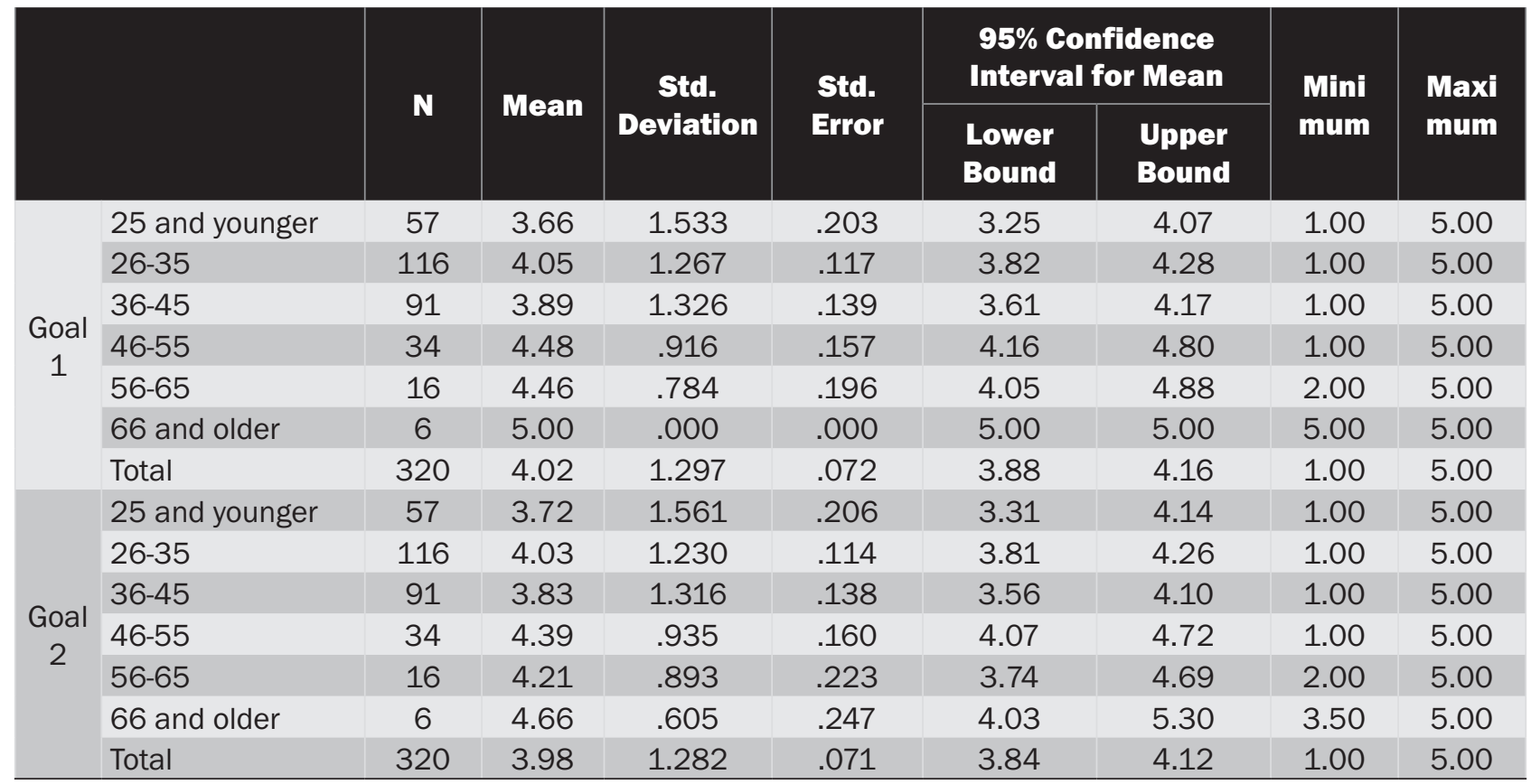

SOURCE: Authors' calculation

TABLE 4. ANOVA

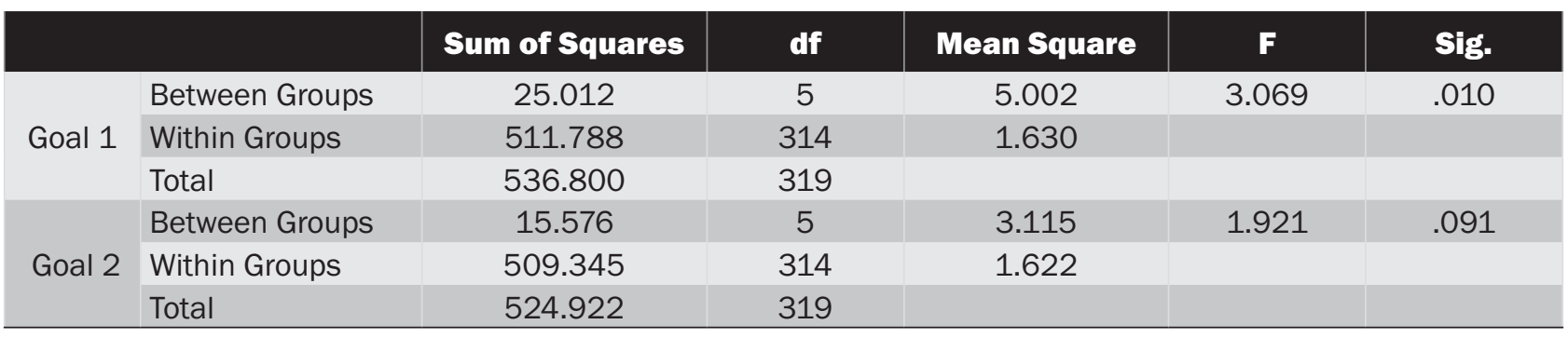

SOURCE: Authors' calculation

analysis of variance helped to determine the existence of a statistically significant difference in goals of slow tourism (goal 1 - self-enrichment, goal 2 - revitalization) between respondents based on their income structure. The respondents were divided into five income groups (group 1: up to 300 euros; group 2: 301600 euros; group 3: 601-900 euros; group 4: 901-1200 euros; group 5: more than 1200 euros). The research results are shown in Table 5 and Table 6.

With regard to goal 1 , the results revealed a statistically significant difference $(\mathrm{p}<0.05)$ between all five groups: $\mathrm{F}(4,315)=4.818, \mathrm{p}=0.001$. The actual difference between the mean values was moderate. The size of the difference, expressed as eta-squared, was 0.06 . Further comparison, using the Tukey HSD test, showed that the mean value for group $1(\mathrm{M}=3.34$; $\mathrm{SD}=1.674)$ differed significantly from the mean value for group $2(\mathrm{M}=4.05 ; \mathrm{SD}=1.323)$, group $3(\mathrm{M}=4.31$;
$\mathrm{SD}=1.029)$, group $4(\mathrm{M}=4.16 ; \mathrm{SD}=1.035)$ and group 5 $(\mathrm{M}=4.10 ; \mathrm{SD}=1.217)$. As far as goal 2 is concerned, the results indicated a statistically significant difference $(p<0.05)$ between all five groups: $F(4,315)=4.900$, $\mathrm{p}=0.001$. The actual difference between the groups' mean values was medium. The size of difference, expressed as eta-squared, was 0.06 . Further comparison, using the Tukey HSD test showed that the mean value for group $1(\mathrm{M}=3,32 ; \mathrm{SD}=1,445)$ differed significantly from the mean value for group $2(\mathrm{M}=4,06 ; \mathrm{SD}=0,882)$, group $3(M=3,98 ; S D=0,984)$ and group $4(M=3,84$; $\mathrm{SD}=1,252)$. Group $5(\mathrm{M}=3,86 ; \mathrm{SD}=0,987)$ did not differ significantly from groups $1,2,3$ and 4 . Having identified a statistically significant difference $(\mathrm{p}<0.05)$ with regard to both goals, one can draw a conclusion that hypothesis $\mathrm{H}_{3}$ is confirmed, i.e. there is a statistically significant difference in goals of slow tourism between respondents based on their income structure. 
TABLE 5. Descriptive statistics

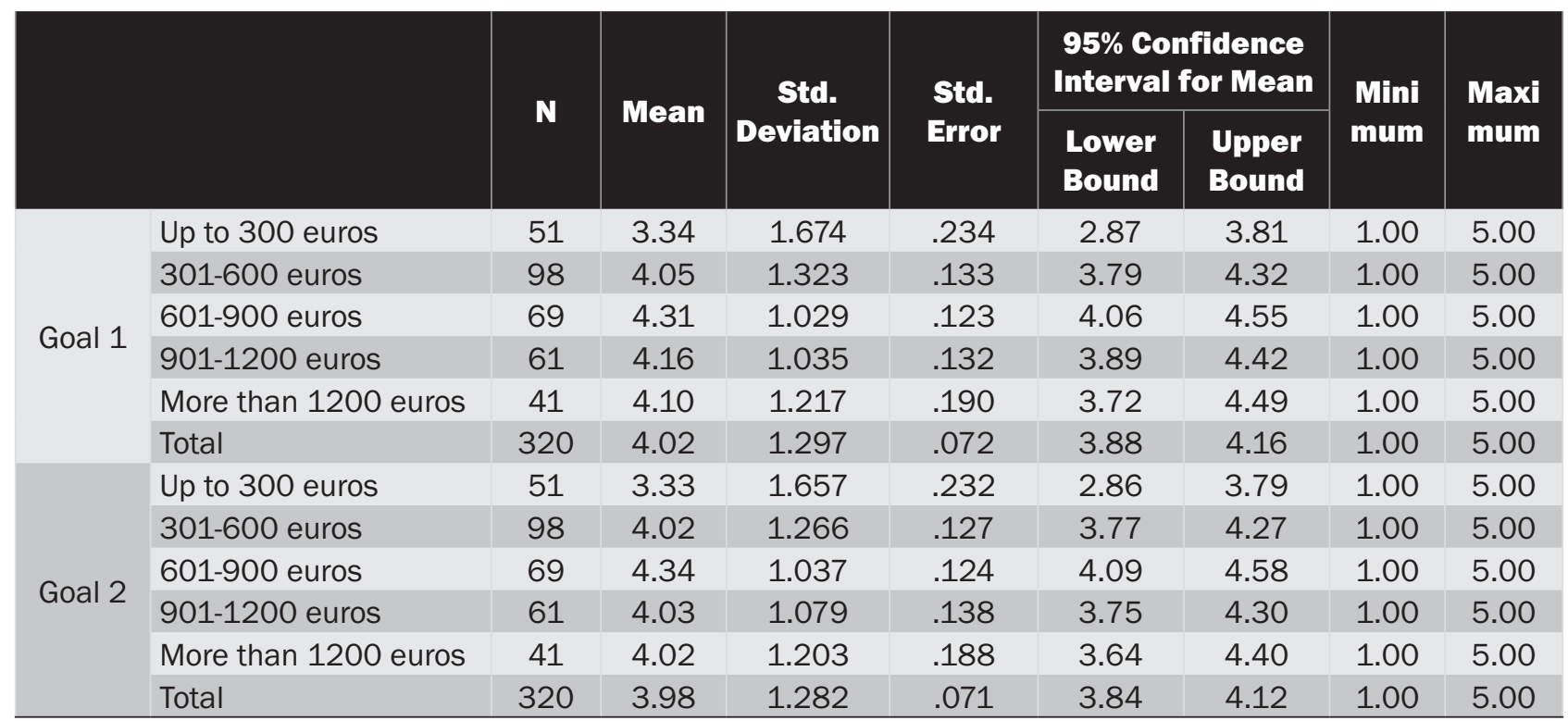

Source: Authors' calculation

TABLE 6. ANOVA

\begin{tabular}{|ll|c|c|c|c|c|}
\hline & & Sum of Squares & df & Mean Square & F & Sig. \\
\hline \multirow{2}{*}{ Goal 1 } & Between Groups & 30.946 & 4 & 7.737 & 4.818 & .001 \\
\cline { 2 - 7 } & Within Groups & 505.854 & 315 & 1.606 & & \\
& Total & 536.800 & 319 & & & \\
\multirow{2}{*}{ Goal 2 } & Between Groups & 30.746 & 4 & 7.686 & 4.900 & .001 \\
& Within Groups & 494.176 & 315 & 1.569 & & \\
\cline { 2 - 6 } & Total & 524.922 & 319 & & & \\
\hline
\end{tabular}

SOURCE: Authors' calculation

\subsection{Determining a statistically significant difference in goals of slow tourism between respondents based on their educational background}

For testing hypothesis $\mathrm{H}_{4}$, one-way analysis of variance was performed (one-way ANOVA). The application of one-way analysis of variance helped to determine the existence of a statistically significant difference in goals of slow tourism (goal 1 - self-enrichment, goal 2 - revitalization) between respondents based on their educational background. According to their educational background the participants were divided into three groups (group 1: high school; group 2: faculty; group 3: $\mathrm{PhD}$ ). The research results are shown in Table 7 and Table 8.

With regard to goal 1 , the results showed a statistically significant difference $(\mathrm{p}<0.05)$ between all three groups: $F(2,317)=3.733, p=0.025$. The actual difference between the groups' mean values was small. The size of the difference, expressed as eta-squared, was 0.02. Further comparison, using the Tukey HSD test indicated that the mean value for group $1(M=3.65$; $\mathrm{SD}=1.544)$ differed substantially from the mean value for group $2(\mathrm{M}=4.10 ; \mathrm{SD}=1.254)$. Group $3(\mathrm{M}=4.26$; $\mathrm{SD}=0.832$ ) did not differ significantly from groups 1 and 2. With regard to goal 2 , the results revealed a statistically significant difference $(\mathrm{p}<0.05)$ between all three groups $\mathrm{F}(2,317)=4.069, \mathrm{p}=0.018$. The actual difference between groups' mean values was small. The size of the difference, expressed as eta-squared, was 0.03. Further comparison, using the Tukey HSD test indicated that the mean value for group $1(\mathrm{M}=3.59$; $\mathrm{SD}=1.534)$ differed substantially from the mean value for group $2(\mathrm{M}=4,07 ; \mathrm{SD}=1.236)$. Group $3(\mathrm{M}=4.17$; $\mathrm{SD}=0.819)$ did not show a significant difference neither from group 1, nor from group 2 . Having detected a statistically significant difference with regard to both goals $(\mathrm{p}<0.05)$, the conclusion is that respondents of different educational backgrounds have different slow 
TABLE 7. Descriptive statistics

\begin{tabular}{|c|c|c|c|c|c|c|c|c|c|}
\hline & & \multirow{2}{*}{$\mathbf{N}$} & \multirow{2}{*}{ Mean } & \multirow{2}{*}{$\begin{array}{c}\text { Std. } \\
\text { Deviation }\end{array}$} & \multirow{2}{*}{$\begin{array}{l}\text { Std. } \\
\text { Error }\end{array}$} & \multicolumn{2}{|c|}{$\begin{array}{l}95 \% \text { Confidence } \\
\text { Interval for Mean }\end{array}$} & \multirow{2}{*}{$\begin{array}{l}\text { Mini } \\
\text { mum }\end{array}$} & \multirow{2}{*}{$\begin{array}{l}\text { Maxi } \\
\text { mum }\end{array}$} \\
\hline & & & & & & $\begin{array}{l}\text { Lower } \\
\text { Bound }\end{array}$ & $\begin{array}{l}\text { Upper } \\
\text { Bound }\end{array}$ & & \\
\hline \multirow{4}{*}{ Goal 1} & High school & 66 & 3.65 & 1.544 & .190 & 3.27 & 4.03 & 1.00 & 5.00 \\
\hline & Faculty & 222 & 4.10 & 1.254 & .084 & 3.93 & 4.26 & 1.00 & 5.00 \\
\hline & $\mathrm{PhD}$ & 32 & 4.26 & .832 & .147 & 3.96 & 4.56 & 1.00 & 5.00 \\
\hline & Total & 320 & 4.02 & 1.297 & .072 & 3.88 & 4.16 & 1.00 & 5.00 \\
\hline \multirow{4}{*}{ Goal 2} & High school & 66 & 3.59 & 1.534 & .188 & 3.21 & 3.96 & 1.00 & 5.00 \\
\hline & Faculty & 222 & 4.07 & 1.236 & .083 & 3.91 & 4.23 & 1.00 & 5.00 \\
\hline & $\mathrm{PhD}$ & 32 & 4.17 & .819 & .144 & 3.87 & 4.46 & 1.50 & 5.00 \\
\hline & Total & 320 & 3.98 & 1.282 & .071 & 3.84 & 4.12 & 1.00 & 5.00 \\
\hline
\end{tabular}

SOURCE: Authors' calculation

TABLE 8. ANOVA

\begin{tabular}{|ll|c|c|c|c|c|}
\hline & & Sum of Squares & df & Mean Square & F & Sig. \\
\hline \multirow{2}{*}{ Goal 1 } & Between Groups & 12.353 & 2 & 6.177 & 3.733 & .025 \\
\cline { 2 - 5 } & Within Groups & 524.447 & 317 & 1.654 & & \\
\cline { 2 - 5 } & Total & 536.800 & 319 & & & \\
\multirow{2}{*}{ Goal 2 } & Between Groups & 13.139 & 2 & 6.569 & 4.069 & .018 \\
& Within Groups & 511.783 & 317 & 1.614 & & \\
\cline { 2 - 6 } & Total & 524.922 & 319 & & & \\
\hline
\end{tabular}

SOURCE: Authors' calculation

tourism goals. In other words, hypothesis $\mathrm{H}_{4}$ is confirmed - there is a statistically significant difference in slow tourism goals between respondents based on their educational background.

\section{DISCUSSION AND CONCLUSION}

According to Oh et al. (2016) "slowness" in tourism is defined as an engagement in a number of behavioral modes while traveling. Achieving the first goal of slow tourism - revitalization - consumers can get refreshed and recharged, while achieving the second goal - self-enrichment - they can get inspired, expand perspectives and connect more deeply to the destination. These two goals result in positive attitude and clear mindset.

Based on the results of this study (and in terms of goals and demographic characteristics of tourists) a slow tourist in Vojvodina is a female, older person with monthly income between 601 and 900 euros and highly educated. This research established who are the Slow Tourists in Vojvodina and highlighted ideas on how „slow" fits in with theories of consumer behav- ior. Results are in line with the claim of Guiver and McGrath (2016), according to whom slow tourists are a growing group of time and cash-rich retirees.

Understanding and predicting slow tourists' behavior is important for developing marketing and management strategies. The results of this study provide a few implications for destination managers and marketers. Firstly, they need to pay attention to potential aspects of slow tourism in their destination. In this sense, slow tourism offers a new vision and perspective for the development of tourism in Vojvodina. Secondly, "slow elements" that can be incorporated within the offer of Vojvodina as a tourist destination are: promote the use of slower transport options (information on public transport and bicycle hire); provide slower environments and tranquil areas (TV free and mobile phone free zones); promote local food and drinks (traditional dishes, traditional products); develop more specific slow products (relaxation/ well-being breaks, slow tours) (Caffyn, 2012). Destination managers should target specific market segments to which slow would suit such as people with stressfull lives or older people who may want a slower paced travel. 
Adopting principles of slow tourism destinations may reduce the financial leakage to foreign suppliers and generate more income by employing local people (Guiver and McGrath, 2016). In that sense, "slow" has the potential to offer a,win win win' situation (Caffyn, 2012): sustainable form of tourism; more economic benefits for a destination; more satisfying experience for consumers.

\section{References}

1. Bagozzi, R.P., Dholakia, U. (1999). Goal Setting and Goal Striving in Consumer Behavior. Journal of Marketing, 63, 19-32.

2. Barbopoulos, I., Johansson, L. (2016). A multidimensional approach to consumer motivation: exploring economic, hedonic and normative consumption goals. Journal of Consumer Marketing, 33 (1), 75-84.

3. Barbopoulos, I., Johansson, L. (2017). The Consumer Motivation Scale: Development of a multi-dimensional and context-sensitive measure of consumption goals. Journal of Business Research, 76, 118-126.

4. Caffyn, A. (2012). Advocating and Implementing Slow Tourism. Tourism Recreation Research, 37 (1), 77-80.

5. Conway, D., Timms, B. (2010). Re-branding alternative tourism in the Caribbean: The case for ,slow tourism. Tourism and Hospitality Research, 10 (4), 329-344.

6. Conway, D., Timms, B. (2012). Are Slow Travel and Slow Tourism Misfits, Compadres or Different Genres?. Tourism Recreation Research, 37 (1), 71-76.

7. Dickinson, J., Lumsdon, L. (2010). Slow Travel and Tourism. UK: Earthscan.

8. Fallon, J. (2012). If you're making waves then you have to slow down: Slow tourism and canals. In a book: Slow Tourism: Experiences and Mobilities, edited by S. Fullagar, K. Markwell, and E. Wilson. Bristol, UK: Channel View, 143-156.

9. Fullagar, S., Markwell, K., Wilson, E. (2012). Slow Tourism: Experiences and Mobilities. UK: Channel View Publications.

10. Gardner, N. (2009). A manifesto for slow travel. Hidden Europe 25. Retrieved from: https://www. hiddeneurope.co.uk/a-manifesto-for-slow-travel

11. Georgica, G. (2015). The Tourist's Perception about Slow Travel - A Romanian Perspective. Procedia Economics and Finance, 23, 1596-1601.
12. Guiver, J.W., McGrath, P. (2016). Slow Tourism: Exploring the discourses. Dos Algarves: A Multidisciplinary e-Journal, 27, 11-34.

13. Lindenberg, S., Steg, L. (2007). Normative, gain and hedonic goal frames guiding environmental behavior. Journal of Social Issues, 63 (1), 117-137.

14. Long, L.M. (2013). Culinary tourism. University Press of Kentucky.

15. Lumsdon, L., McGrath, P. (2011). Developing a conceptual framework for slow travel: a grounded theory approach. Journal of Sustainable Tourism, 19 (3), 265-279.

16. Meng, B., Choi, K. (2016). The role of authenticity in forming slow tourists' intentions: Developing an extended model of goal-directed behavior. Tourism Management, 57, 397-410.

17. Moore, K. (2012). "On the Periphery of Pleasure: Hedonics, Eudaimonics, and Slow Travel." In a book: Slow Tourism: Experiences and Mobilities, edited by S. Fullagar, K. Markwell, and E. Wilson. Bristol, UK: Channel View, 25-35.

18. Novak, T.P., Hoffman, D.L., Duhachek, A. (2003). The Influence of Goal-Directed and Experiential Activities on OnlineFlowExperiences. Journal of Consumer Psychology, 13 (1/2), 3-16.

19. Oh, H., Assaf, A.G., Baloglu, S. (2016). Motivations and Goals of Slow Tourism. Journal of Travel Research, 55 (2), 205-219.

20. Parasecoli, F., Lima, P.A. (2012). Eat your way through culture: Gastronomic tourism as performance and bodily experience. In a book: Slow tourism aspects of tourism: Experiences and mobilities, edited by Simone, F., Kevin, M., Wilson, E. NY: Channel View Publications, 69-83.

21. Yurtseven, H.R., Kaya, O. (2011). Slow Tourists: A Comparative Research Based on Cittaslow Principles. American International Journal of Contemporary Research, 1 (2), 91-98. 


\section{marketing}

\section{Sažetak:}

\section{Ciljevi potrošača u kontekstu Slow turizma}

Slavica Tomić, Ksenija Leković, Dražen Marić

U uslovima naglašene potrebe za usporavanjem tempa življenja koncept Slow turizma dobija na značaju. Ovaj koncept vezuje se za pojam održivog turizma i društvene pokrete poput: „Slow Food“ (autentična, lokalna hrana), "Slow Cities“ (ekološki odgovorna i mirna okruženja) and „Slow Transportation“ (lokalni vidovi transporta). U radu je objašnjen fenomen Slow turizma iz perspektive ciljnousmerenog ponašanja potrošača. Istraživanje se baziralo na modelu kojeg čine: motivi (opuštanje, samorefleksija, beg, otkrića, angažovanje i učenje), ciljevi (revitalizacija i samoobogaćenje) i ishodi putovanja (zadovoljstvo, ponovni dolazak u destinaciju i preporuke). Uzorak je obuhvatio 320 ispitanika sa teritorije Republike Srbije koji su u prethodne dve godine posetili neku od destinacija u Vojvodini označenu kao „slow place“.

Ključne reči: Slow turizam, ponašanje potrošača, ciljevi potrošača, Vojvodina

Kontakt:

Slavica Tomić, tomics @ef.uns.ac.rs Ksenija Leković, ksenija.lekovic@ef.uns.ac.rs Dražen Marić, drazen.maric@ef.uns.ac.rs

Univerzitet u Novom Sadu, Ekonomski fakultet u Subotici Segedinski put 9-11, 24000 Subotica 